\title{
Legal Policy in the Sky of Higher Education as A Strategy for Empowering Indonesia Society
}

\author{
David $^{1}$, Azis Budianto ${ }^{2}$ \\ Universitas Borobudur, Jakarta, Indonesia ${ }^{1,2}$ \\ \{davied7321@gmail.com¹, azis_budianto@borobudur.ac.id²
}

\begin{abstract}
Renewing the education policy system is a conscious and planned effort to create an atmosphere of learning and the learning process so that students can actively develop their potential to have religious-spiritual strength, self-control, intelligence, and skills needed by themselves, the community, the nation, and state. The purpose of education is to educate the lives of all Indonesian people without exception, the current higher education curriculum is competency-based which refers to academic qualifications. The reason for the reform of the higher education policy system is because the quality of higher education graduates has not been able to answer the needs and global competitiveness. As well as the imbalance between the profile of higher education graduates and the workforce qualification standards required by the job market. Provisions regarding the requirement for education providers and/or educational units to be in the form of educational legal entities are still on the legal agenda of this country. Article 53 of the National Education System Law No.20 / 2003 mandates the drafting of a law on education legal entities. Previously, Law No. 9/2003 on Education Legal Entities was issued, but the Constitutional Court declared it "non-binding" on March 31, 2010.
\end{abstract}

Keywords: Autonomous management of education; legal entities; education providers

\section{Preliminary}

The basis of education policy in Indonesia is stipulated in Article 31 of the 1945 Constitution [1] and spelled out in Law Number 20 of 2003 concerning the National Education System [2] and supported by the existence of Law Number 32 of 2004 concerning Regional Government in Article 1 paragraph (5) which states that regional autonomy is the right, authority, and obligation of an autonomous region to regulate and manage government affairs by itself, and the community interest according to the laws and regulations [3].

Indonesia has 138,22 million employees in 2020. With the following specification: the number of unemployed 9,77 million people and the workers are 128,45 million people [4]. This figure is obtained from the residents aged over 15 years old. BPS Data showed that the Indonesian workers' participation rate is at $67,77 \%$ while the ratio of the working population to the labor force is $62,98 \%$ [4]. This figure indicates that the total working population is about $12-17 \%$, over $50 \%$ of the working-age population. This number is still not high. 
Remembering that in 2030, Indonesia will get a demographic bonus. If the absorption rate of personnel is not high, it will be the potential to become a problem in the future. One of the requirements to be employed is to have an appropriate educational qualification. For this reason, education becomes one of the factors that support the absorption of the workforce in Indonesia.

Based on PISA (Program for International Students Assessment) data, over 50\% of students in Indonesia who aged more than 15 years old do not expertise basic knowledge such as reading and mathematics [5]. Although the data was taken in 2015, however, this is in the line with Fauzie's writing (2018) in CNN Indonesia online daily which states that more than $55 \%$ of Indonesian children are illiterate [6]. Furthermore, quoting Welle's article (2019) on the online news' page of detik.com, turns out that Indonesia's education rankings in the fields of science, mathematics, and reading are still in the 60s below Singapore, Vietnam, and Thailand [7]. The portrait of Indonesian education from 2015 to 2019 has not experienced significant development, although it has not decreased but not increased in terms of basic skill mastery.

Higher education as the last level of education has a role that is not simple because, at this point, it is expected that the graduates will be able to be absorbed and compete in the global world of work. However, based on BPS data in 2020, the contribution of the labor force from higher education is around $12,39 \%$ [8]. This number is still lower than the contribution rate of secondary education graduates, namely at 31,96\%. This indicates that university graduates have not made a huge contribution to the working field in Indonesia. The higher education graduates are expected to be able to contribute to employment in Indonesia because at this level, their income is higher than other education alumni.

One of the driving factors in education development is education policy. It is issued by the government through laws and regulations. Through the determined policies, the director of higher education will be purposed at the expected goals. Thus, this research will examine how policies in higher education can be an alternative strategy to empower the human resources of Indonesian education.

\section{Method}

This research is a literature study, wherein this research, the researcher examines the facts in the field based on the result of a literature study, which then will be combined with an analysis of existing laws and regulations. Based on this design, this research is qualitative because it is intended to explore the problems surrounding higher education and the prevailing laws and regulations in Indonesia. The result of this research is expected to be a recommendation or suggestion for stakeholders to empower and improve the quality of human resources for higher education in Indonesia.

\section{Result and Discussion}

\subsection{Indonesian Education Condition}

Based on the data exposure above, the condition of Indonesian education is still beneath the quality line. Never mind the quality, it hasn't caught up to follow the average standard. The low quality of education in Indonesia is caused by several factors. Such as the imbalance of 
access to education in Indonesia. Although so far, infrastructure development and policies have been launched by the government to equalize the education quality. In fact, equality through access to education has not been achieved. Based on the world bank report in Fauzie (2018), education access is still disproportionally and imbalanced [6]. Thus, it is a challenge for the government to distribute education. Besides, the management and effectiveness of children's learning at school are also an issue that needs attention. Remembering these two things often become a problem in the world of education.

The factual condition of Indonesia in the education world will be a challenge to this country to face the industrial revolution 4.0 and 5.0 society. Harususilo (2019), states that there are at least three problems in the education world in Indonesia based on the result of the SMSG conference, such as quality, access, and equity [9]. Meanwhile, based on the quality paradigm from Sallis (2002), the quality of an educational institution will be achieved if can meet the needs of its customers [10]. Based on this paradigm, the quality in the world will be achieved. What matters now is what can be defined as customer needs. For stakeholders, who are graduates employers, what is needed is qualified graduates who are ready to work under science and technology developments. For prospective graduates and society, what is expected is a higher education that can meet the required quality in the world of work so that they are ready to go directly into the world of work. With Indonesia's geographical condition as well as other diversity, then differences of education quality from one to another place are an emerging issue. Even though the business world and industry expect similarities from existing graduates. Based on the explanation above, the factual need for Indonesian education is equal access to education so that the improvement in the quality of education will occur.

To provide equal access to education, the steps taken by the government at this time have been a milestone for the striving for equal access to facilities. Because with the adequate infrastructure, every people can easily access educational facilities. For example, the bridge construction will ease for children to reach schools in remote areas, highway construction will facilitate the distribution of educational facilities such as textbooks, and so on. Of course, infrastructure development should be accompanied by technology and information infrastructure. For example, the internet and computer equipment to remote areas. The internet program to enter villages has begun to be promoted, but not only the internet that has been developed, but also facilities such as signal transmitter and so on to facilitate communication. This is because there are still many communication facilities that are not evenly distributed in several regions.

After infrastructure development, the next step is the development of human resources. The independent learning program, both in the primary education and higher education areas, is one of the government's flagship programs to match the needs of the business world and industry. One of the programs in it is the existence of a campus teaching program to strengthen the education and education institutions (Dikdasmen) [11]. Some local governments have also started sending their youth to study at leading universities, both at home and abroad that have teacher training and education majors. So that later, after the youth of this area have finished studying, they can return to their area and build education in their respective regions.

Although this has not shown a significant real impact, slowly but surely this will provide a change in the equality of education in Indonesia. Even so, the government cannot relax and linger in the development of this education. Because the era of disruption that is happening has changed everything to the root and in the shortest possible time. Everything can change very quickly. For this reason, the government needs to think about accelerating growth and developing the equal distribution of facilities and access to education in Indonesia. Motivating 
the best human resources to develop regions can be a way of equalization. After motivating is to regenerate each cell growth of human resources to the local population. Construction of facilities ranging from elementary schools to tertiary institutions in the regions is of course an option that will increase the competitiveness of Indonesian human resources. Acceleration and acceleration of infrastructure and human resources development are very necessary considering that Indonesia will also enter the demographic bonus phase accompanied by the 4.0 industrial revolution and the 5.0 society. All of these conditions require effective and efficient management of education and flexibility and can adapt to these fast-paced changes.

\subsection{Development of Higher Education Policies in Indonesia}

Higher education policies in Indonesia play an important role in determining the direction of higher education in Indonesia. Policy developments in the field of education in Indonesia occur in line with the needs that exist in society [12]. This indicates that the policy on education is progressive and not just standing still.

Talking about higher education policy will boil down to the quality of higher education. The development of higher education policies in Indonesia is affiliated with the integrated quality management of education [13]. This is intended so that higher education in Indonesia will be able to build a quality culture in the implementation of its management.

Referring to Law Number 20 of 2003 concerning the National Education System, higher education institutions must be able to develop science and technology so that they can have an impact on society in the form of education, research, and community service [2]. This higher education obligation is then referred to as the tri dharma of college. Fulfillment of the tri dharma of higher education is required to remain oriented towards meeting the quality of education. This is stated in law number 12 of 2012 concerning higher education [14]. This law does not stand by itself but also has a companion regulation, namely Permendikbud Number 50 of 2014 concerning the Internal Higher Education Quality Assurance System [15]. In both laws and regulations, higher education institutions are required to have an internal quality assurance system as evidence of achieving educational quality standards. This system includes education, research, and community service. The application of this internal quality assurance system borrows many theories from the integrated quality management paradigm. This internal quality assurance system is also a requirement for the higher education external quality assurance system, namely accreditation. Higher education accreditation is an absolute requirement that must be met by higher education institutions, if an institution is not accredited then that institution will not have a license to operate. Where the end of this quality assurance system is the implementation of quality culture and continuous improvement. This shows that higher education policies have an orientation towards integrated quality management.

The internal quality assurance system in higher education starts from the cycle of determining quality standards, implementation, evaluation, control, and also improvement. This stage is a cycle where when the last stage has been completed it will return to the first stage. When returning to the initial stage here what is meant is not to repeat but to increase or enter into a new level. At the end of a cycle, there is a stage of improvement. In this case, this increase is intended so that the system being built can enter a new level. So that the existing cycle tends to have an increasing graph that fulfills the principle of continuous improvement that exists in the integrated quality management paradigm of education. Looking at this explanation, the laws and regulations made direct higher education institutions to be able to maintain and improve their quality. If the higher education institution has met the existing 
quality standards, a quality culture will be implemented in that institution. With the implementation of this quality culture, it is possible that in the future the role and function of the government in supervising the quality of higher education institutions will be increasingly fruitful. Because universities that already have a qualified quality assurance system will be able to adjust to conditions in the community.

To standardize quality standards in higher education, the government issued laws and regulations on existing quality standards. The regulation issued by the minister of education and culture is the Regulation of the Minister of Education and Culture of the Republic of Indonesia Number 3 of 2020 concerning National Higher Education Standards [16]. In this Permendikbud regulates national standards for higher education and higher education standards. National higher education standards are the minimum standard requirements that must be met by a higher education institution. This standard applies absolutely and is applied by all higher education institutions in Indonesia. This standard includes 3 main parts, namely education, research, and community service with each section divided into eight standards, with a total of 24 quality standards for this national standard. Meanwhile, higher education standards are the standards set by the higher education institutions themselves. Higher education standards are an increase from the national higher education standards. Thus, a university is required to exceed the national standards set by the government. The existence of this regulation further emphasizes how quality culture is accustomed to entering higher education institutions. Permendikbud number 3 has also stipulated independent learning for higher education institutions. This policy of independent learning is intended to make higher education institutions freer to develop themselves so that they can adapt to the needs in the field. This freedom also applies to students to be able to take courses in other study programs and to choose their practicum activities. This is intended so that students can feel the experience of being in the world of work faster than the existing curriculum.

The quality policy issued by the government for higher education institutions does prioritize the implementation of a quality culture but on the other hand for institutions that cannot follow this policy, it will be difficult to obtain accreditation. If it does not meet the quality standards that have been determined then the accreditation will fail and cannot continue the operation of the university again. Thus, the existing policies and regulations are like two sides of a coin. On the one hand, this policy will improve the quality of higher education institutions and on the other hand, this policy will bulldoze universities that are unable to adjust. In this case, a strategic step is needed to bridge all existing interests.

\subsection{Community Empowerment through Higher Education Policies}

Seeing the problem of labor absorption from universities into the business world and the industrial world, a strategy from higher education policies is needed in the process of community empowerment. Through the higher education policies that have been discussed previously, it can be seen that the orientation of higher education policies is in quality culture. The quality paradigm held by universities will be able to improve the quality of learning management. To be able to improve this quality paradigm, the role of higher education policy takes a fairly large portion [17].

Higher education policies can increase the empowerment of Indonesian society. By increasing the quality of higher education, it will improve the quality of human resources [18]. In higher education policy, the tri dharma of higher education is the main focus. In the field of education, when the quality of education is maintained and improved, it will produce students and graduates who can be absorbed in the world of work. Learning that stimulates students to 
be able to continue to innovate and adapt to developments in science, technology, and art will be a breakthrough for the world of higher education. Student training to work in the world of work will further enhance student abilities. This policy is contained in the minister of education's policy of independent learning which is also in the Minister of Education and Culture Regulation number 3 of 2020 [16]. Thus, students will not be surprised when later they have to go directly to the world of business and industry.

Policies in the research sector will encourage the world of higher education to continue to innovate. Both lecturers and students and researchers will produce new findings in the fields of science, technology, and arts (IPTEKS) that will help improve the welfare of human life. For example, the discovery of a nasal detection tool for COVID-19 by UGM (Gajah Mada University) proves that research results from universities can contribute to society [19]. These findings are just one example of a variety of other similar research results that can help improve science and technology for Indonesians. Thus, Indonesia can also compete at the international level through existing research results. Therefore, research policies in higher education need to be continuously studied and developed to make a real contribution to society.

Likewise, dedication to the community of higher education can share knowledge with the community by sharing the results of their research or through other activities that can empower the community. Extension and various pieces of training will be able to answer the various challenges that exist. However, this too should be protected by the policy. Existing policies should not only demand but also facilitate. So that practice in the field does happen dedication, not just fulfillment of obligations due to accreditation demands.

Various policies in higher education in Indonesia lead to empowerment and improvement of people's lives [20]. For some higher education institutions, this policy in the form of demands will be burdensome or even deadly. However, this will be a natural selection for higher education institutions because institutions that practice will endure and develop, while institutions that only exist will die and disappear.

\section{Conclusion and Suggestion}

Higher education policy is a chain of command to determine the goals of higher education in Indonesia. The existing policies to date are oriented towards improving and empowering the human resources of the Indonesian people. This is evidenced by the emphasis on educational outcomes, research dissemination, and community service. However, for some existing policy institutions, it is like a heavy burden and leads to the closure of the institutions. For this reason, existing policies should continue to be reviewed so that Indonesian higher education institutions will not be closed and replaced by foreign educational institutions. Because standards that are too high without any process will be a barrier for Indonesian higher education institutions.

In this study, only a picture of higher education policy is taken. Other factors that can influence community empowerment by higher education institutions have not yet been identified. Therefore, further research can see and identify the existence of other factors that affect community empowerment by higher education institutions.

\section{References}


[1] Undang-Undang Dasar Negara Indonesia. Jakarta, Indonesia, 1945.

[2] Undang-Undang Republik Indonesia Nomor 20 Tahun 2003 Tentang Sistem Pendidikan Nasional. Jakarta, Indonesia, 2003.

[3] UU Nomor 32 Tahun 2004 tentang Pemerintahan Daerah. Jakarta, Indonesia, 2004.

[4] Sub-directorate of Statistical Analysis, National Employment Survey. Jakarta: BPSStatistics Indonesia, 2020.

[5] OECD, Education In Indonesia: Rising To The Challenge. Paris: OECD Publishing, 2015.

[6] Y. . Fauzie, "Bank Dunia: Kualitas Pendidikan Indonesia Masih Rendah,” 2018. https://www.cnnindonesia.com/gaya-hidup/20180607113429-284-304214/bank-duniakualitas-pendidikan-indonesia-masih-rendah.

[7] D. Welle, "Potret Pendidikan Indonesia di Tengah Perkembangan Teknologi," 2019. https://news.detik.com/dw/d-4533564/potret-pendidikan-indonesia-di-tengahperkembangan-teknologi.

[8] Sub-directorate of Statistical Analysis, Employment Workforce Indicator Indonesia 2020. Jakarta: BPS-Statistics Indonesia, 2020.

[9] Y. . Harususilo, "Soal Utama Pemberdayaan Pendidikan di Indonesia," 2019. ttps:/edukasi.kompas.com/read/2019/02/20/07300091/3-soal-utama-pemberdayaanpendidikan-di-indonesia.

[10] E. Sallis, Total quality management in education: Third edition. 2014.

[11] Kemdikbud, "Kampus Mengajar Angkatan 1 Tahun 2021, Upaya Kemendikbud Libatkan Mahasiswa dalam Penguatan Pembelajaran di Sekolah Dasar pada Masa Pandemi," 2021. https://dikti.kemdikbud.go.id/kabar-dikti/kabar/kampus-mengajarangkatan-1-tahun-2021-upaya-kemendikbud-libatkan-mahasiswa-dalam-penguatanpembelajaran-di-sekolah-dasar-pada-masa-pandemi/.

[12] S. Octavianus, "The Cultivation of Indonesia's Education Financing Policy in Disruption Era," Int. J. Adv. Soc. Econ., vol. 1, no. 1, p. 16, 2019, doi: 10.33122/ijase.v1i1.36.

[13] A. . Soegito, Total Quality Management (TQM) di Perguruan Tinggi. Semarang: UNNES Press, 2011.

[14] Undang-Undang nomor 12 Tahun 2012 tentang Pendidikan Tinggi. Indonesia, 2012.

[15] Permendikbud Nomor 50 Tahun 2014 tentang Sistem Penjaminan Mutu Internal Perguruan Tinggi. Indonesia, 2014.

[16] Peraturan Menteri Pendidikan Dan Kebudayaan Republik Indonesia Nomor 3 Tahun 2020 Tentang Standar Nasional Pendidikan Tinggi. Indonesia, 2020.

[17] S. Octavianus, Y. . Sukestiyarno, Rusdarti, and E. Pramono, Suwito, "Improving Theological Seminary Human Resources' Quality Mind-Set in Disruption Era,” Jun. 2020, [Online]. Available: https://dx.doi.org/10.2991/assehr.k.200620.077.

[18] M. I. Hendri and Ramadhania, "APLIKASI TQM PADA MANAJEMEN PERGURUAN TINGGI: SUDUT PANDANG KEPEMIMPINAN, KOMITMEN ORGANISASIONAL DAN MANAJEMEN SDM,” J. Ekon. Bisnis dan kewirausahaan, vol. 1, pp. 116-128, 2010.

[19] C. G. Asmara, "Alat Deteksi Covid-19 UGM GeNose Dipasarkan, Harga Rp 25 Ribu," 2020. https://www.cnbcindonesia.com/tech/20201226090132-37-211610/alat-deteksicovid-19-ugm-genose-dipasarkan-harga-rp-25-ribu.

[20] Kisbiyanto, "Manajemen Kebijakan Sumber Daya Manusia Pendidikan : Studi Kasus di STAIN Kudus,” Edukasia J. Penelit. Pendidik. Islam, vol. 9, no. 1, pp. 129-146, 2014. 
